レーザーオリジナル

\title{
レーザー鍼で引き起こされる人体皮膚組織内の 熱応力分布
}

\author{
石川昌広 ${ }^{*} \cdot$ 藤 原 修 ${ }^{*} \cdot$ 加藤一夫 ${ }^{*}$. 阿座上 孝 $*$
}

（1988年 3 月30日 受理）

\author{
Spatial Distribution of Thermal Stress inside Human \\ Skin Tissue caused by Laser Acupuncture \\ Masahiro ISHIKAWA*, Osamu FUJIWARA*, Kazuo KATOH*, \\ and Takashi AZAKAMI*
}

(Received March 30, 1988)

Laser acupuncture is recognized as the biostimulation therapy with a low energy laser, while the mechanism has not been clear. However, in the pulsed laser acupuncture, the thermal stress caused by the photo-acoustic effect is thought to be the dominant factor of the biostimulation.

This paper proposes a method of calculating the spatial distribution of the thermal stress in side a human skin tissue using Hu's model for analyzing the photo-acoustic wave in the liquid. Numerical calculations show that the shape of the thermal stress depends on the absorption coefficient of the laser, that is, the stress due to the $\mathrm{CO}_{2}$ laser occurs sharply compared with the case of the YAG laser.

Key Words: Laser acupuncture, Biostimulation, Thermal stress analysis, Calculation.

\section{1.まえがき}

「レーザー鍼」とは，P $\log の$ 提案になる低 エネルギーレーザー光を用いた無侵襲鍼療法を いう1)。この療法は，東洋医学の「鍼炎療法」 に類似する神経刺激療法の一種とされ，従来の いわゆる鍼治療に比して無痛であり，しかも感 染の可能性も全くないので, 近年の半導体レー ザーの発達・普及と相まって世界各国で盛んに 行われるようになった2!。我が国では，神川 (明治鍼尒大学)らがレーザー鍼を用いた腰痛 ・ 神経痛の疼痛除去, 運動障害・末梢循環障害の
改善などの臨床例を数多く報告している ${ }^{3,4)}$

レーザー鍼の治療効果には目を兒張るものが あるが，発現機序は未だ明らかでない ${ }^{5,6) 。 ~}$

一般に，レーザー光照射による生体刺激効果 は定性的には (1)光作用 (2)電磁界作用 (3)熱作用 (4)圧力作用とに分けて説明されてはいるものの, いずれが支配的であるかは現時点においては不 明である。しかしながら、レーザー鍼のように 照射ビームの平均出力が数百 $\mu \mathrm{W}$ から数十 $\mathrm{mW}$ の低エネルギーレーザー光では(2)(3)は考えにく く，(1)(4)が有力となろう。レーザー銊をパルス モードで使用する際には尖頭出力は数Wにも達 するが（中国の獣医鍼尒では尖頭出力 $5 \mathrm{~W} の$

*名古屋工業大学工学部電気情報工学科 (T466 名古屋市昭和区御器所町)

* Department of Electrical and Computer Engineering, Faculty of Engineering, Nagoya lnstitute of Technology (Gokiso-cho, Showa-ku, Nagoya 466). 
$\mathrm{CO}_{2}$ レーザーが実際に使用されている $\left.{ }^{21}\right)$ ，この 程度でも(2)の影響は小さいとしてよく，また， その場合の臨床例によれば照射部位には熱感を 伴わずに機械的刺激感覚を生ずるという息(パル スレーザー鍼では数百 $\mathrm{ns}$ から数 $\mu \mathrm{s}$ の短時間照 射を数百 $\mathrm{Hz}$ の周波数で繰り返すので平均出力 は高々数 $\mathrm{mW}$ 程度が普通である)。このことは, パルスモードのレーザー鍼では(4)が優勢に働い ているように思わせる。したがって，レーザー 鍼による治療効果の発現機序を工学的見地から 検討するには，第一段階として，レーザ一光照 射による圧力作用の刺激因子を分析し，これを 定量的に把握しておくことが必要不可欠であろ うと筆者らは考える。この観点から, 本論文で は，パルスモードのレーザー鍼で人体皮膚組織 内に引き起こされる圧力刺激のうち最も強く発 現するであろう熱応力 ${ }^{7}$ を考察の対象に選び8-13), これの空間分布の計算法を提案し, 併せて治療 条件が発生熱応力に及ぼす影響を定量的に明ら かにする。

\section{2. 理論}

レーザー鍼による熱応力はレーザー光を照射 した皮膚組織内での急激な熱膨張に起因して発 生する。これを求めるには皮膚組織内部でのレ 一ザー光の吸収電力分布から過渡的な上昇温度 を知り，つぎに組織変位に関する熱弾性方程式 を解かねばならない。この場合の熱応力を解析的 に導出することは一般には困難である。本論文 では, $\mathrm{Hu}$ の提案になるレーザー光照射での急速 加熱による液体内の音響波計算モデル ${ }^{14)}$ を応用 し、これからパルス照射で人体皮䖉内部に生ず る熱応力の計算式を導出して示す。

\section{1 レーザー光照射と温度上昇}

熱応力の解析に際しては, 皮膚組織を均一な 半無限弾性体とみなし, 組織内部の位置はレー ザースポットの中心を $R=0$ としたO- $R \theta \phi の$ 球座標系で表す。Fig. 1は液体を対象とした $\mathrm{Hu}$ の提案 ${ }^{14)}$ になるレーザー光の照射モデル (a) と 吸収電力分布(b) を示す。図のモデルでは，ビ

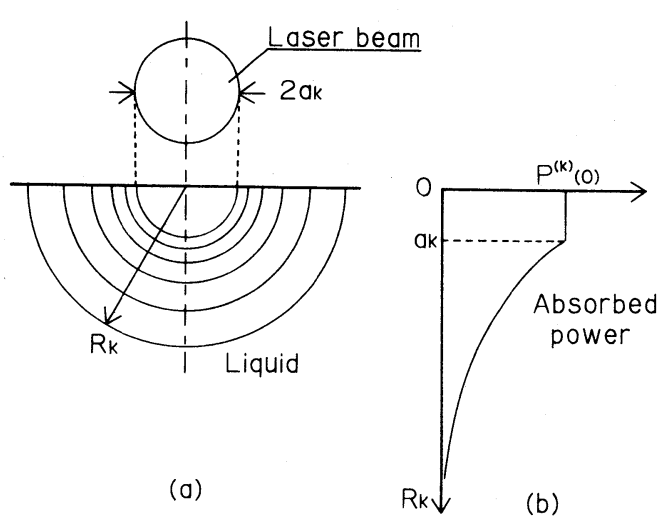

Fig. $1 \mathrm{Hu}$ 's model of (a) configuration of laser beam irradiation and (b) absorbed power distribution.

一ム径が $2 \mathrm{a}_{\mathrm{K}}$ のレーザー光の単位体積あたりの 吸収電力 $P^{(\mathrm{K})}\left(R_{\mathrm{K}}\right)$ は $0 \leqq R_{\mathrm{K}} \leqq \mathrm{a}_{\mathrm{K}}$ の半球領域に おいては一定値 $P^{(\mathrm{K})}(0)$ で, 距離 $R_{\mathrm{K}} \geqq \mathrm{a}_{\mathrm{K}}$ の 範 囲ではスポットを中心とした放射状に指数減衰 するとしている。しかしながら, 人体皮虐組織 に照射したレーザー光はビームスポットの直下 で照射方向に大部分浸透・減衰するので, この

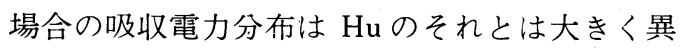
なる。本論文では, レーザー光を照射した皮膚 組織における吸収電力は照射方向に対して軸対

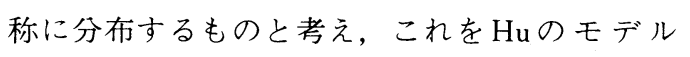
で合成する。即ち, レーザー光を多数の微小な フィラメントビームで合成し, 各微小ビームの吸 収電力分布に $\mathrm{Hu}$ のモデルを適用するのである。 Fig. 2 は筆者らの解析モデルと座標系を示す。 但し、レーザースポットの中心を $r=0$ とした $O-r \theta z$ の柱座標系で組織内部の位置を表す。 レーザー光の出力電力を $E_{0}$, ビーム径を $2 a$, 座標 $(r, \theta, z)$ における単位体積あたりの吸収 電力を $P(r, z)$ として, この場合のレーザ一 光を $N$ 個のフィラメントビームで合成する。そ のとき, $k$ 番目 $(k=1,2,3, \cdot \cdot N)$ のフィ ラメントビームの出力電力を $E^{(\kappa)}{ }_{0}, \quad$ スポット 径を $2 a_{\mathrm{K}}$ とするときは，これらと $E_{\circ}, 2 a$ との 間には

$$
\begin{aligned}
& E_{0}=\sum_{K=1}^{N} E^{(\kappa)_{0}} \\
& \pi a^{2}=\sum_{K=1}^{N} \pi a_{k}^{2}
\end{aligned}
$$


という関係式が得られる。次に, 座標 $\left(R_{k}, \theta_{k}, \phi_{k}\right)$ における単位体積当りの吸収電力を $P^{(k)}\left(R_{k}\right)$ と すれば，これは文献 14）で解析的に求められて いるので, 結局, 座標 $(r, \theta, z)$ でのレーザー 光の吸収電力 $P(r, z)$ と座標 $\left(R_{k}, \theta_{k}, \phi_{k}\right)$ での フィラメントビームの吸収電力 $P^{(k)}\left(R_{k}\right)$ との間 には,

$$
\begin{aligned}
P(r, z) & =\sum_{k=1}^{N} P^{k)}\left(R_{k}\right) \\
& =\sum_{k=1}^{N} \frac{3 E_{0}^{(k)} \alpha_{k}^{3}}{2 \pi\left(A_{k}^{3}+3 A_{k}^{2}+6 A_{k}+6\right)} \\
& \cdot \exp \left[-\alpha_{k}\left(R_{k}-a_{k}\right) U\left(R_{k}-a_{k}\right)\right]
\end{aligned}
$$

という関係式が成り立つ, ここで,

$$
\left.\begin{array}{l}
R_{k}=\sqrt{\left(r-r_{k}\right)^{2}+z^{2}} \\
A_{k}=\alpha_{k} a_{k}
\end{array}\right\}
$$

であり, $U(\cdot)$ は単位ステップ関数である。 また, $a_{k}$ は皮膚組織内部のレーザー光の吸収 電力分布 $P(r, z)$ の形状を決定する係数である。

つぎに，フィラメントビームの吸収電力 $P^{(k}$ $\left(R_{k}\right)$ によ上昇温度を求める。本論文ではレ 一ザー光のパルス照射で生ずる熱応力を解析の 対象とするので, 皮膚表面での熱放散・組織内 部の熱伝導および血流による冷却効果は無視で きるものとする。そのとき, パルス幅 $t_{0}$ のフ イラメントビーム照射による上昇温度 $\tau^{(k)}$ $\left(R_{k}, t\right)$ は

$$
\begin{aligned}
\tau^{(k)}( & \left.R_{k}, t\right)=P^{(k)}\left(R_{k}\right) / \rho C \\
& \times\left[t-\left(t_{0}+t\right) \cdot U\left(t-t_{0}\right)\right]
\end{aligned}
$$

で与えられる。ここで， $\rho, C$ はそれぞれ人体 皮膚組織の密度, 比熱である。

\section{2 熱応力の計算式}

レーザー光照射による発生熱応力は, 各フィ ラメントビームで生ずるそれを導出し, これら を重ね合わせれば求まる。まず， $k$ 番目のフィ ラメントビームによって発生する熱応力を導出 する。上昇温度 $\tau^{(\kappa)}$ は式(4) から $R k_{0}$ 方向だけに

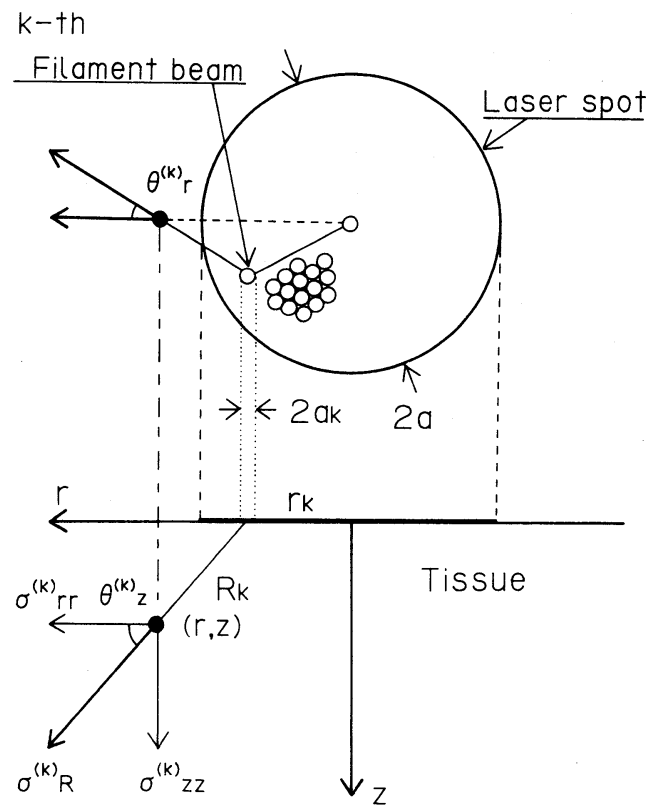

Fig. 2 Proposed model for calculating spatial distribution of thermal stress and its coordinate system.

依存するので, 変位を $u_{k}$, 熱応力を $\sigma^{(\kappa)}{ }_{R}$ とすれ ば，球座標系の熱弾性方程式は，

$$
\begin{aligned}
& \rho \frac{\partial^{2} u_{k}}{\partial t^{2}}=\frac{B}{R_{K}^{2} \sin \theta_{k}}\left(\frac{\partial}{\partial R_{k}}\left(R_{k}^{2} \sin \theta_{k} \frac{\partial u_{k}}{\partial R_{k}}\right)\right. \\
& \left.+\frac{\partial}{\partial \theta_{k}}\left(\sin \theta_{k} \frac{\partial u_{k}}{\partial \theta_{k}}\right)+\frac{\partial}{\partial \phi_{k}}\left(\sin \theta_{k} \frac{\partial u_{k}}{\partial \phi_{k}}\right)\right] \\
& +\frac{B \beta}{R_{k}^{2}} \frac{\partial}{\partial R_{k}}\left(R_{K}^{2} \tau^{(k)}\right) \\
& \sigma^{(k)}=-B\left[\frac{1}{R_{k}^{2}} \frac{\partial}{\partial R_{k}}\left(R_{k}{ }^{2} u_{k_{R}}\right)\right. \\
& \quad+\frac{1}{R_{k} \sin \theta_{k}} \frac{\partial u_{k \Phi}}{\partial \phi_{k}} \\
& \left.\quad+\frac{1}{R_{k} \sin \theta_{k}} \frac{\partial}{\partial \theta_{k}}\left(\sin \theta_{k} u_{k \theta}\right)\right]
\end{aligned}
$$

初期条件 : $\left.u_{k}\right|_{t=0}=0$

$$
\left.\frac{\partial u_{k}}{\partial t}\right|_{t=0}=0
$$

境界条件 : $\left.\sigma^{(k)}{ }_{R}\right|_{R_{K}=0}=\left.\sigma_{R}^{(k)}\right|_{R_{K}=\infty}=0$ 
と表わされる。ここで, $B$ は弾性モジュラス, $\beta$ は熱膨張係数であり, $u_{k R}, u_{\kappa \theta}, u_{k \Phi}$ は $u_{k}$ の $R, \theta, \phi$ 成分である。式(5), (6)を式(7)の条件 で解くと, 熱応力は距離 $R_{k}$ だけの関数で解析 的に導出でき ${ }^{14)}$,

$$
\begin{gathered}
\sigma_{R}^{(k)_{R}(t)=} \frac{B \beta \tau}{\alpha v t_{0}}\left[\frac{f\left[\alpha v\left(t-R_{k} / v\right)\right]}{2 \alpha R_{k}}\right. \\
\left.-\frac{f\left[\alpha v\left(t-t_{0}-R_{k} / v\right)\right]}{2 \alpha R_{k}}\right] \\
f(x)=\left\{\begin{array}{c}
(1-x) \exp \left(x+\alpha a_{k}\right) \\
-\alpha\left(R_{k}-a_{k}\right) \leqq x<-\alpha a_{k} \\
1+A+\left(A^{2} / 2\right)-\left(x^{2} / 2\right) \\
-\alpha a_{k} \leqq x<\alpha a_{k} \\
(1+x) \exp \left(-x+\alpha a_{k}\right) \\
\alpha a_{k} \leqq x \\
\tau=P_{k}\left(a_{k}\right) /(\rho C)
\end{array}\right.
\end{gathered}
$$

と表わされる。ここで，vは熱応力の伝搬速度 である。結局, レーザー光照射による発生熱応 力は $\sigma^{(k)}{ }_{R}$ を重ね合わせれば求められ， $z$ 成分を $\sigma_{z z}, r$ 成分を $\sigma_{r r}$ とするときは，これらはFig.

2 で示すように,

$$
\begin{aligned}
& \sigma_{z z}(r, z, t)=\sum_{k=1}^{N} \sigma_{R}^{(k)}(t) \sin \theta_{z} \\
& \sigma_{r r}(r, z, t)=\sum_{k=1}^{N} \sigma^{(k)}{ }_{R}(t) \cos \theta_{z} \cos \theta_{r}
\end{aligned}
$$

で与えられる。

\section{3. 数值計算例}

実際に臨床で使用されているレーザー鍼は波 長 $600 \sim 10,000 \mathrm{~nm}$, 出力数百 $\mu \mathrm{W}$ から数十 $\mathrm{mW}$ のレーザー光を患部に数十秒から数十分間, 連 続照射またはパルス照射して行われているとい j ${ }^{15)}$ 。本章では, 代表的なレーザー光の単発パ ルス照射で人体皮膚組織内に引き起こされる熱 応力の空間分布を数值的に示し，ついで照射条 件の影響を調べる。

3.1 計算諸量と方法
レーザー鍼を実施する対象は黄色人種の皮膚 組織とする。計算諸量は皮膚組織の比熱として $C=3.35 \mathrm{~J} / \mathrm{g} \cdot{ }^{\circ} \mathrm{C}$, 熱膨張係数として $\beta=4.1 \times$ $10^{-5} /{ }^{\circ} \mathrm{C}$, 熱応力波の伝搬速度として $v=1.57$ $\times 10^{5} \mathrm{~cm} / \mathrm{s}$ の数值を文献 $(7)$ から引用した。レ 一ザー光の吸収係数 (波長と生体組織とに依存) ・パルス幅・ビームスポット径の発生熱応力に 及ぼす影響を調べるために，臨床使用のレーザ 一のうち皮膚組織に対する光吸収の度合が両極 端である $\mathrm{CO}_{2}$ レーザーとYAGレーザーを計算 の対象に選ぶ。即ち, $\mathrm{CO}_{2}$ レーザー光（波長 $\lambda=$ $10,600 \mathrm{~nm}$, 黄色人種に対する吸収係数 $\alpha=$ $200 / \mathrm{cm})$ は皮膚組織の表面で大部分吸収される のに対してYAGレーザー（波長 $\lambda=1,060 \mathrm{~nm}$, 黄色人種に対する吸収係数 $\alpha=10 / \mathrm{cm})$ では皮 膚組織に深く浸透する ${ }^{16)}$ ので, これらのレーザ 光照射による熱応力発生の相違を調べれば十分 であろう。レーザー光の照射条件は尖頭出力電

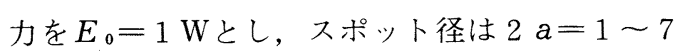
$\mathrm{mm}$ ，パルス幅は $t_{0}=1 \mathrm{~ns} \sim 10 \mu \mathrm{s}$ する。Fig. 3 は $\mathrm{CO}_{2}$ とYAGレーザー光のスポット径を共に $3 \mathrm{~mm}$ とした照射で単位体積あたりの皮膚組織内
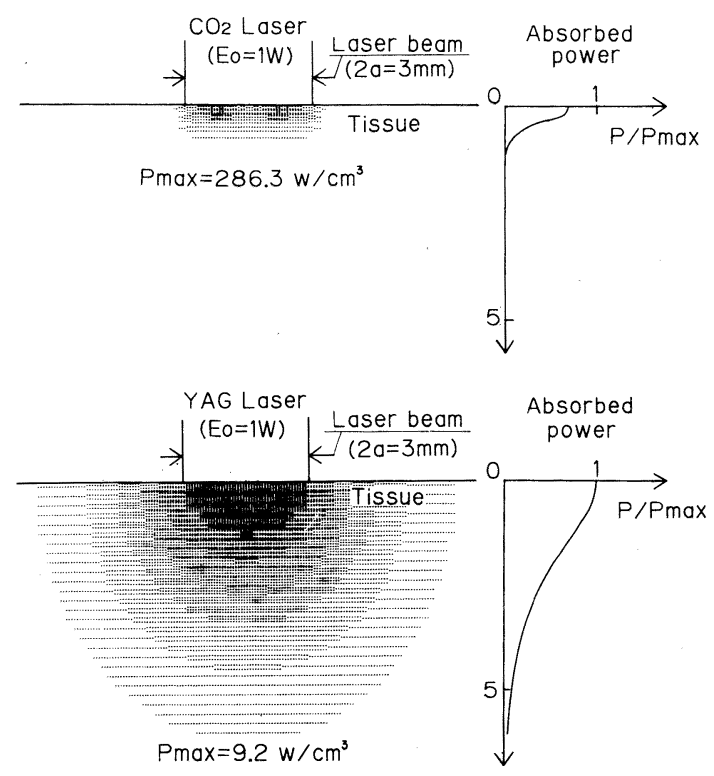

Fig. 3 Absorbed power distributions inside human skin tissue irradiated by $\mathrm{CO}_{2}$ and YAG laser beams. 
に吸収される電力分布の式(2)による計算結果を 示す。ここで，レーザー光は均一のフィラメン トビームでつぎのように合成した。即ち, $\mathrm{CO}_{2}$ とYAGレーザー光照射による吸収電力 $P(r$, $z)$ を文献 16） のそれと一致させるようにフ イラメントビームの個数を $N=130$ とし，これ と式(1)とから各ビームの出力電力およびスポッ 卜径はそれぞれ $E^{(k)}{ }_{0}=7.14 \mathrm{~mW}, 2 \mathrm{a}_{k}=0.23$ $\mathrm{mm}$ とし。但し，各フィラメントビームの形状 係数 $\alpha_{k}$ は, YAGレーザー光については径方向 で変化させ, $\mathrm{CO}_{2}$ レーザー光ではすべて同じと した。なお，数值例で取り扱うレーザー電力 1 Wは比較的大出力であるが，本論文では $1 \mathrm{~ns}$ か $ら 10 \mu \mathrm{s}$ 程度の短時間の単発パルス照射を対象 とするので，例えば，レーザー光のパルス幅を $10 \mu \mathrm{s}$ ，繰り返し周波数を500 $\mathrm{Hz}$ とすれば平均 電力としては $1 \mathrm{~W} \times 10 \mu \mathrm{s} \times 500 \mathrm{~Hz}=5 \mathrm{~mW}$ で 極めて低出力となる。

\section{2 計算結果と考察}

Fig. 4 はスポット径が $3 \mathrm{~mm}$ でパルス幅が 2 $\mu \mathrm{s}$ の $\mathrm{CO}_{2}$ とYAGレーザー光の単発照射によっ

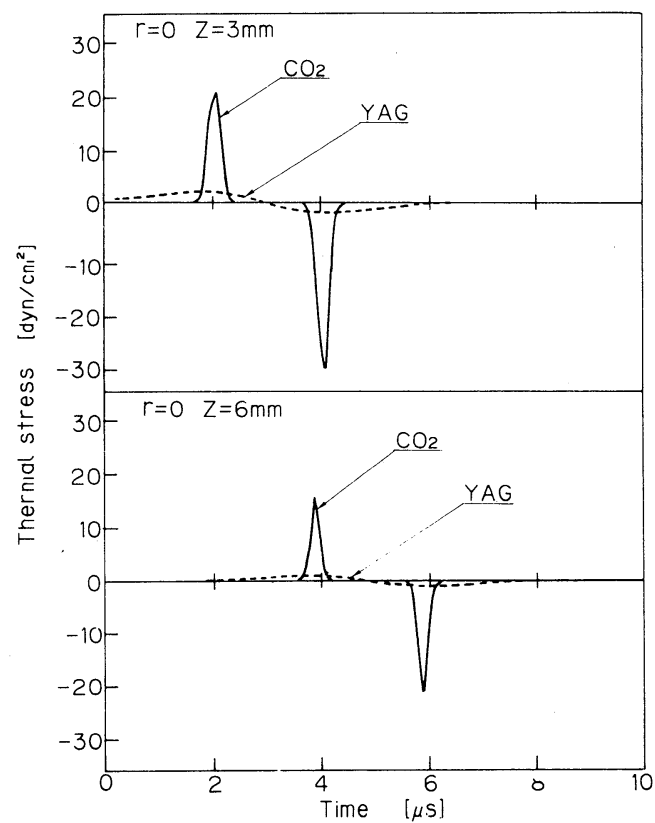

Fig. 4 Calculated waveforms of thermal stresses.
て皮虞組織内に発生する熱応力波形の式(9)によ る計算結果を示す。図から，単発パルス照射に よる熱応力は正方向にピークをもつ膨張波と負 方向にピークをもつ圧縮波とからなる, $\mathrm{CO}_{2}$ レ ーザー光照射による熱応力は YAG の場合より もインパルス状に発生しており，その最大值 （負のピーク）は31.4 dyn $/ \mathrm{cm}^{2}$ に達し, 同一電 力の YAGレーザーのそれより16倍程度大きい こと，などが知られる。Fig. 5 はFig. 4のレー ザー光照射後 $t=5 \mu \mathrm{s}$ における熱応力 $\sigma_{z z}$ の空 間分布を, Fig. 6 は同条件での熱応力 $\sigma_{r r}$ の空 間分布をそれぞれ等高線で示す。但し，図中の 数值は等高線值であり, 熱応力の大きさの最大 值を 9 段階に分けて表している。これらの図か ら, $\mathrm{CO}_{2}$ レーザー光照射による熱応力は局所的 に発生していること, その尖頭值はレーザー光 照射面直下で生じていること, などがわかる。 Fig. 7 は熱応力尖頭値の照射パルス幅の依存 性を示す。図によると, 応力尖頭値はパルス幅 が長いほど増大し， あるパルス幅を越えると飽 和していること，そのパルス幅は $\mathrm{CO}_{2}$ レーザー
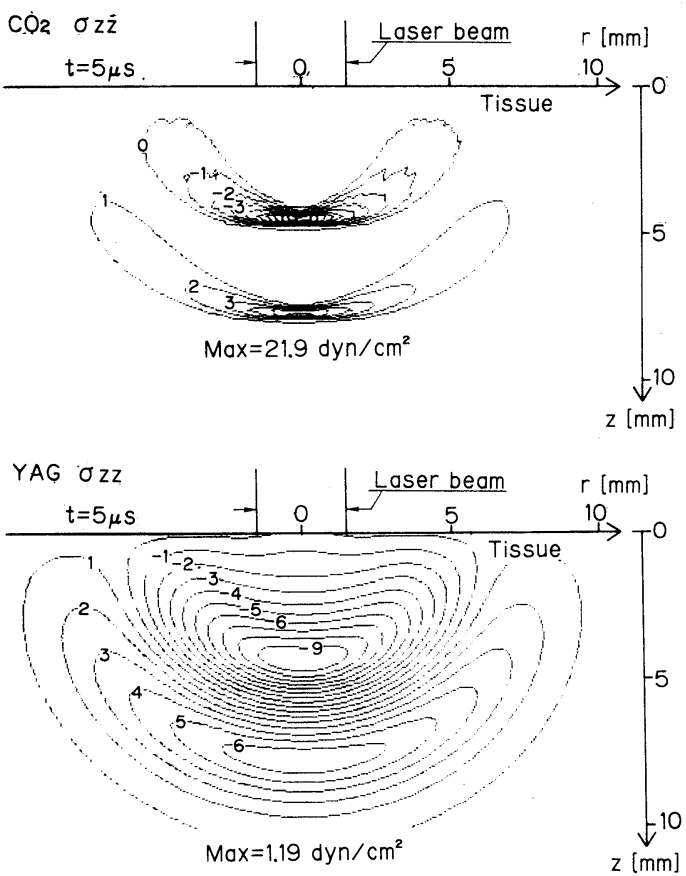

Fig. 5 Spatial distribution of thermal stress $\sigma_{z Z}$. 


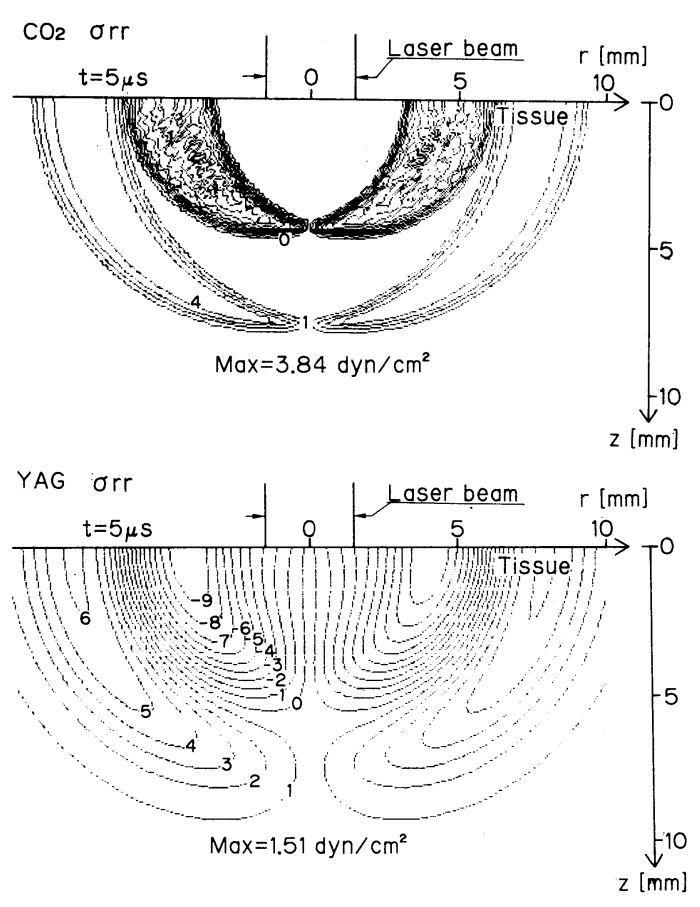

Fig. 6 Spatial distribution of thermal stress $\sigma_{r r}$.

の場合は数百 $\mathrm{ns}$ 程度で $\mathrm{YAG}$ では数 $\mu \mathrm{s}$ 程度で あることなどが知られる。この理由はつぎのと おりである。パルス幅が短い場合は膨張波と圧 縮波が重なり合うので応力尖頭值は小さいが, パルス幅が長くなると膨張波と圧縮波とが分離 するので応力尖頭值が飽和するのである。その パルス幅は, 熱応力波形が鋭いほど短くなるの で, 吸収係数の大きい $\mathrm{CO}_{2}$ レーザーのほうがYAG の場合より短くなるのである。また，図から， 応力尖頭值はスポット径が大きいほど減少する こと, その程度はレーザー光の吸収係数が大の ほど大きく, 例えば, $\mathrm{CO}_{2}$ レーザー光による応 力尖頭値はスポット径を 7 倍（電力密度は約50 分の 1 ）にすると応力尖頭值は10分の 1 に激減 するのに対し，YAGレーザー光では半分程度 に減少することなどがわかる。

以上, 臨床使用で代表的な $\mathrm{CO}_{2}$ とYAGレー ザーについてパルスモードの照射条件が発生熱 応力に及ぼす影響を定量的に調べた。連続モー

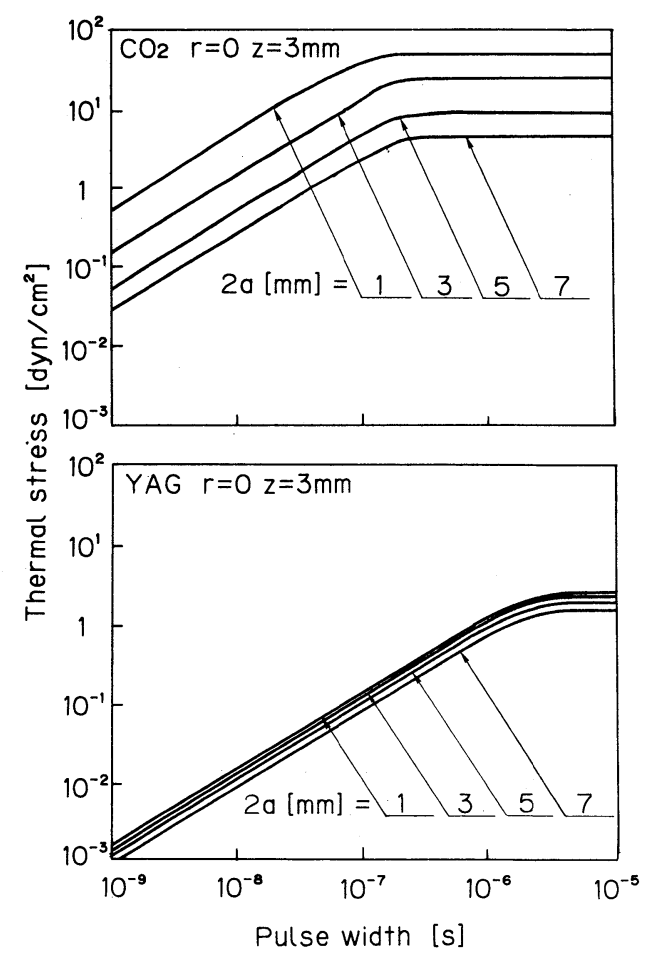

Fig. 7 Dependences of pulse width on peak values of thermal stresses.

ドのレーザー鍼においては, Fig. 4 から照射直 後に単発の熱応力波が生じること, Fig. 7 から 応力尖頭値はレーザー光の出力電力とスポット 径とで定まること,などがそれぞれ読み取れる。 したがって, 照射ビームの連続出力が数 $\mathrm{mW}$ 程 度のレーザー鍼においては熱応力は照射直後に しか生じないこと, 応力尖頭值は同一の平均電 カ・スポット径のパルスモードでのそれより数 千分の一倍と極めて小さくなること, などがわ かる。このことは連続モードでのレーザー光照 射による刺激効果が圧力よりはむしろ光作用で 生ずることを想像させるものであるが, 同作用 による刺激効果には不明な点が多く, 今後の研 究に期待される。

なお, 最近のレーザー鍼で頻用されはじめた 半導体レーザーについては, 人体皮膚組織に対 する吸収係数が今のところ明かではないが, 組 織内の吸収電力分布を知れば照射条件に応じた 
発生熱応力を本文の計算式で求められることは いうまでもない。

\section{4. むすび}

レーザー鍼による刺激因子のうち圧力刺激と なる熱応力を取り上げ，これの計算式をレーザ 一光諸量との関係において導出し，代表的な治 療条件における発生熱応力の空間分布を明らか にした。計算式は，照射レーザー光を多数のフ イラメントビームで合成し, 各微小ビームの照 射で発生する熱応力を $\mathrm{Hu}$ のモデルから求め, これらを重ね合わせて導出した。 $\mathrm{CO}_{2}$ と $\mathrm{YAG}$ レーザー光の単発パルス照射で発生する熱応力 の数値計算の結果, 人体皮䖉組織内で発生する 熱応力はレーザー光の吸収係数が大のほど時間 的にも空間的にも鋭くなること，パルス幅が長 いほど発生熱応力の尖頭值は増加して飽和する こと，そのパルス幅は吸収係数が大のほど短い こと，スポット径が小さいほど熱応力の尖頭値 は増加すること，その依存性は吸収係数が大の ほど顕著に現れること，などの知見が得られた。

レーザー光照射による発生熱応力が神経系に どのような刺激を与えるかは現時点においては 全く不明ではあるが, レーザー銊で照射条件を 考慮しながら治療を行い, その効果とレーザー 光照射条件との関係を把握することが今後の課 題である。

\section{参考文 献}

1) 神川, 田和, 香山, 一兒, 中村：レーザー研 究, 14 (1985), pp. 202-207.
2) ”低エネルギーレーザー医学国際シンポジウ ム (International Symposium on Low Energy Laser in medicine and Surgery, Tokyo '85)" (1985) p. 22, 66.

3）例えば，神川喜代男：”レーザー刺激による 血行変動に関する研究”, 昭58厚生省特定疾患 スモン調査研究班研究業績集抜刷, V-A 3, V-A3 (1983), pp. 473-475.

4) 神川, 田和, 香山：日本レーザー医学会誌, 5 (1985), pp. 215-220.

5) 藤原, 岡田, 加藤, 阿座上: 名古屋工業大学 学報, 38 (1986), pp. 171-176。

6) 岡田, 藤原, 加藤, 阿座上：レーザー研究, 15 (1987), pp. 38-43.

7) 柴田, 藤原, 加藤, 阿座上：信学論 $(B)$, J69-B (1986), pp. 1144-1146.

8) 石川, 藤原, 加藤, 阿座上 : “Laser acupuncture による熱座力の計算”, 昭和 61 年東海連 大, No. 361, 362 .

9) 石川, 藤原, 加藤, 阿座上：信学技報 (1986) EMCJ86-61.

10）石川, 藤原, 加藤, 阿座上： “Laser acupuncture で発生する熱応力の 3 次元解析”, 昭和 62年東海連大, No. 332 .

11）石川，藤原，加藤，阿座上：信学技報 (1987), EMCJ87-86.

12）石川, 藤原, 加藤, 阿座上：”レーザー鍼で人 体皮膚組織内に生ずる熱応力の計算”, 信学総 全予稿, B301.

13) M. Ishikawa, O. Fujiwara, K. Katoh, T. Azakami: "Calculation of Thermal Stress inside Skin Tissue produced by Laser acupuncture", Trans. IEICEJ, E71 (1988), pp. 369-371.

14) C. L. Hu: J. Acoust. Soc. Amer., 46(1969), pp. 728-736.

15) 大西, 神川：医学のあゆみ, 124 (1983), pp. 589-594.

16）渥美和彦監修：”レーザーの臨床”, （メディ カルプランニング, 1981年) p. 239. 